\title{
UNIVERSITYOF
}

FORWARD

THINKING

WESTMINSTER用

WestminsterResearch

http://www.westminster.ac.uk/westminsterresearch

\section{An Intramuscular Approach to Teacher Development in International Collaborative Higher Education \\ Breen, $\mathbf{P}$.}

This is a copy of the final, typeset PDF of the author manuscript of a book chapter published in Mukerji, S. and Tripathi, P. (eds.) Handbook of Research on Transnational Higher Education, IGI Global, pp. 368-390.

It is reprinted with permission and is available from the publisher at:

https://dx.doi.org/10.4018/978-1-4666-4458-8.ch019

Copyright (C) 2014, IGI Global. Copying or distributing in print or electronic forms without written permission of IGI Global is prohibited.

The WestminsterResearch online digital archive at the University of Westminster aims to make the research output of the University available to a wider audience. Copyright and Moral Rights remain with the authors and/or copyright owners.

Whilst further distribution of specific materials from within this archive is forbidden, you may freely distribute the URL of WestminsterResearch: ((http://westminsterresearch.wmin.ac.uk/)).

In case of abuse or copyright appearing without permission e-mail repository@westminster.ac.uk 


\section{Handbook of Research on Transnational Higher Education}

Siran Mukerji

IGNOU, India

Purnendu Tripathi

IGNOU, India

Volume I

A volume in the Advances in Higher Education and Professional Development (AHEPD) Book Series 


$\begin{array}{ll}\text { Managing Director: } & \text { Lindsay Johnston } \\ \text { Editorial Director: } & \text { Joel Gamon } \\ \text { Production Manager: } & \text { Jennifer Yoder } \\ \text { Publishing Systems Analyst: } & \text { Adrienne Freeland } \\ \text { Development Editor: } & \text { Monica Speca } \\ \text { Assistant Acquisitions Editor: } & \text { Kayla Wolfe } \\ \text { Typesetter: } & \text { Lisandro Gonzalez } \\ \text { Cover Design: } & \text { Jason Mull } \\ & \\ \text { Published in the United States of America by } \\ \text { Information Science Reference (an imprint of IGI Global) } \\ \text { 701 E. Chocolate Avenue } \\ \text { Hershey PA 17033 } & \\ \text { Tel: 717-533-8845 } & \\ \text { Fax: 717-533-8661 } & \\ \text { E-mail: cust@igi-global.com } & \\ \text { Web site: http://www.igi-global.com }\end{array}$

Copyright (C) 2014 by IGI Global. All rights reserved. No part of this publication may be reproduced, stored or distributed in any form or by any means, electronic or mechanical, including photocopying, without written permission from the publisher. Product or company names used in this set are for identification purposes only. Inclusion of the names of the products or companies does not indicate a claim of ownership by IGI Global of the trademark or registered trademark.

\section{Library of Congress Cataloging-in-Publication Data}

Handbook of research on transnational higher education / Siran Mukerji and Purnendu Tripathi, editors. pages $\mathrm{cm}$ Includes bibliographical references and index.

Summary: "This book is a unique compilation of the most recent research done by higher education professionals in the areas of policy, governance, technology, marketing, and leadership development, highlighting the most important strategies and policies for professionals, policy makers, administrators, and researchers interested in higher education management"-Provided by publisher.

ISBN 978-1-4666-4458-8 (hardcover) -- ISBN 978-1-4666-4459-5 (ebook) -- ISBN 978-1-4666-4460-1 (print \& perpetual access) 1. Transnational education. 2. Education, Higher--Research--Cross-cultural studies. 3. Universities and colleges-Administration--Cross-cultural studies. 4. Education, Higher--Marketing--Cross-cultural studies. 5. Educational technology--Cross-cultural studies. 6. Education and globalization--Cross-cultural studies. I. Mukerji, Siran. II. Tripathi, Purnendu, $1975-$

LC1095.H36 2014

378.1'75--dc23

2013014344

British Cataloguing in Publication Data

A Cataloguing in Publication record for this book is available from the British Library.

All work contributed to this book is new, previously-unpublished material. The views expressed in this book are those of the authors, but not necessarily of the publisher. 


\title{
Chapter 19
}

\section{An Intramuscular Approach to Teacher Development in International Collaborative Higher Education}

\author{
Paul Breen \\ University of East Anglia, UK
}

\begin{abstract}
This chapter looks at a practical example of staff development and considers how professional development of teachers should be an essential component of enhancing provision within higher educational institutions not just in terms of pedagogy but also in respect of developing programmes and marketing those programmes. Set within the specific context of English Language teaching for international students, the research is based on a case study of two trainee teachers on a DELTA programme (Diploma in English Language Teaching for Adults). These teachers have been interviewed at two different stages of their development, firstly whilst doing the DELTA course, and then one year later, by which time they have completed the course. Through analysing their responses in a qualitative fashion, the author examines whether teacher development has a positive impact on the higher educational institution as a whole, and whether it leads to an improved student experience or a heightened consciousness of that student experience on the part of teachers. At the heart of this chapter, there is a metaphor taken from Medical Science to define the best approach to teacher education and development, namely, what the author labels an intramuscular approach. The author takes this term from a medical process of giving injections that are placed deep within muscles so that the particular drug or medicine is released slowly over a period of time rather than in a standard one-shot manner. There is no quick fix solution to teacher development, and having a long-term vision contributes far more to organisations in terms of the ultimate student experience.
\end{abstract}

DOI: $10.4018 / 978-1-4666-4458-8 . c h 019$

Copyright $\odot$ 2014, IGI Global. Copying or distributing in print or electronic forms without written permission of IGI Global is prohibited. 


\section{INTRODUCTION}

In the medical world, there are two different common forms of injection; subcutaneous and intramuscular, with the latter being one that is "given directly into the central area of a specific muscle" (www.enotes.com) so that after injection "the excretion is much slower" (www.lexic.us). This means that the fluid substance of the injection is released over time rather than immediately as a one-shot solution. As such, it is a form of treatment particularly suited to patients getting some form of long-term treatment such as gene therapy or hormone replacement. The medicine, within the muscle, is released over a period of months rather than in a single dose, meaning that it offers long rather than short term forms of treatment.

In the medical literature, numerous papers have described ways in which this form of treatment has been used in the battle against particular ailments. However, it also serves as a useful analogy for the best practices of contemporary teacher education. Long-term approaches to development have taken on greater significance because of the increasing emphasis upon the student experience, particularly in the context of United Kingdom higher education. If students are to have a good experience, they need good and experienced teachers who understand their individual needs and how to address those needs.

\section{BACKGROUND}

\section{The Student Experience}

Much has been written about the student experience in terms of what it entails, how it should be defined, and how it can be measured (Cook \& Leckey, 1999; Lowe \& Cook, 2003; Bryson $\&$ Hand, 2007). At the heart of this is a sense of engagement with learning which goes back as far as Astin (1984) and Chickering and Gamson (1987); leading to further exploration in the work of Kuh (2001; and 2006), and the more socio-constructivist theories espoused by writers such as Weber (2004). Socio-constructivism in this instance means that participants are actively engaged in defining and understanding the world on their own terms.

It is therefore 'engagement' which essentially defines the student experience. Trowler (2010), in a substantive literature review on student engagement, states that "a sound body of literature has established robust correlations between student involvement in a subset of 'educationally purposive activities', and positive outcomes of student success and development, including satisfaction, persistence, academic achievement and social engagement" (p.2). This has led to a greater emphasis on students being given a voice and a sense of partnership in higher education.

Less has been written about how this relates to teaching and the role that teachers play in being at the interface of this student experience. Ramsden (2009, p. 2) outlines how the nature of higher educational study in the United Kingdom has changed over the past couple of decades, but argues that "the quality of teaching" and particularly the focus on "personal attention to students and on the achievement of high level learning outcomes, has been sustained in the face of sizeable pressure on resources" (ibid). Therefore, using another biological analogy, engagement has become the sinew holding together the learning process, within which teachers have a vital role to play through being at its interface.

This need for quality teaching, according to Ramsden, has developed a culture of professionalism within UK Higher Educational teaching (2009, p. 4). One outcome of this has been the creation of "The UK Professional Standards Framework for teaching and supporting learning in higher education'. This framework, launched 
in 2006, and reproduced in 2011, uses a descriptor based approach to professional standards and outlines one of its key aims as being to support "the initial and continuing professional development of staff engaged in teaching and supporting learning" (2011, p. 2). This is then connected to a further aim of demonstrating "to students and other stakeholders the professionalism that staff and institutions bring to teaching and support for student learning" (ibid).

Thus, it is apparent there is an inherent recognition of the role that teaching plays in the student experience and the need to make the importance of this explicit to the students. Ramsden (2009, p. 5) goes as far as suggesting that students are now "engaged collaborators" in the teaching process and that "inadequate teaching techniques are no longer easily tolerated" (ibid). Of course this has been a feature of English Language Teaching for most of the past few decades, not just in terms of the way that the subject is taught but also in the way that its teachers are educated.

Long before other disciplines placed the same value on engagement, ELT had realised the need for what Trowler (2010) defines as "feelings and sense making as well as activity" (p.5); linking together Fredricks, Blumenfeld and Paris's three dimensions of student engagement - behavioural, emotional, and cognitive (2004, pp. 62-63). This is evidenced by the emphasis on approaches such as Communicative Language Teaching and Task Based Learning which have been widely used in ELT in recent decades. English Language Teaching, though often seen as a poor relation of higher education, has constantly needed to be ahead of the game to provide a quality service. One reason for this is that English Language Teaching as an industry has always needed to have a more commercial focus than other sectors of education. A further positive linked to this has been the need to place good teachers in the English Language classroom and, because of the lack of formal qualifications in the field, to ensure continuous professional development both inside and out of the classroom.

\section{MAIN FOCUS OF THE CHAPTER}

\section{Terminology of Teacher Education}

Crandall (2000, p. 34) states that it is important to note that "language teacher education is a microcosm of teacher education, and many of the trends in current language teacher education derive from theory and practice in general teacher education." Motteram (2004) states that "different approaches are to some extent historical, but may also be seen as representing different perspectives on the way that knowledge is formulated and presented."

A drawback of these differing perspectives is that they can sometimes be seen to muddy the waters of terminology. Evans (2002, p. 123) contends that "in the teacher development literature, very few definitions of teacher development may be found." This is because very often the terms teacher development and teacher education are interchangeable, particularly when used as a contrast to 'training' as in Roberts (1998, pp. 221-222). Indeed any analysis of the literature will reveal a proliferation of terms.

Thus, to some extent, Evans' (2002) assertion bears weight but others would argue that packaging 'teacher education' into a one-size-fits-all definition is not the fundamental element. It is important to outline the historical and epistemological differences in training and development, causing this proliferation of terms to arise. Furthermore it should be stressed that 'training' came before 'development' (Richards, 2008) through "short training programs and certificates ..... designed to give prospective teachers the practical classroom skills needed to teach the new methods" (ibid, p. 2). Much of this was done at the outset of the teachers' 
careers and there was no sense that this had to be continued with unless the teacher wanted to move into a more specialized field such as the teaching of linguistics (ibid). Gradually though there was a movement towards the importance of teacher learning, and the social nature of that learning, rather than teachers being taught (ibid, pp. 5-7).

Part of the driving force behind this was a reaction against courses where teachers are "surreptitiously pushed in pre-determined directions" (Tomlinson, 2003,p.2).Edge (2003,p. 7), drawing on Widdowson (1983) and cited in Mann (2005, p. 104) states that "to train is to instil habits or skills, and the word collocates just as happily with dogs and seals as with teachers." Mann (ibid, p. 105) suggests that teacher education is a "bottom up process" that values the "insider" view whilst training is "top down" and places more emphasis on the "outsider" view. He then concludes that teacher development "is a continuous process of becoming and can never be finished" (ibid).

Borg (2006, p. 99), citing Golombek and Johnson (2004, pp, 323-324), argues that teacher development is "socially situated and socially mediated, non-linear, dialogic, and without an endpoint." This has echoes of what Goodwyn (1997, p. 115) earlier described as a "developmental continuum." Schlager and Fusco (2003, p. 205) add that "professional development is viewed as a career-long, context-specific continuous endeavour that is guided by standards, grounded in the teacher's own work, focused on student learning, and tailored to the teacher's stage of career development."

This emphasis on reflective approaches to teacher development and teacher education is further charted in Shulman (1988), Pennington (1990), Richards and Lockhart (1994), and Roberts (1998, pp. 25-27). Mann (2005) outlines a further argument that teachers themselves must take responsibility for their own learning. The importance of this self-direction is supported in the literature by Stuart and Thurlow (2000); Bailey, Curtis and
Noonan (2001); Crookes and Chandler (2001); and Gibbons and Norman (1987, p. 110) who use the term "self-directed professional development."

\section{Overview of the Delta}

Kelly (2005) states that the DELTA is a "course which, most ELT teacher educators would agree, provides sound training" along with "opportunities for reflection and development." Furthermore it has the added benefit of a practical teaching component, unlike many Masters' programmes which are delivered in theoretical form only. It also holds the distinction of being "the only teaching diploma placed at Level 7 of the UK's Qualification and Credit Framework (QCF)" (Sokol, 2011) which makes it equal to a masters degree or professional diploma. Borg (2011, p. 371) describes this as "an internationally recognized advanced course for practising teachers" which consists of three modules and seeks to "reflect contemporary views of good practice in language teacher education."

These three modules are "designed and produced by University of Cambridge ESOL Examinations" according to the officialDELTA modules handbook produced by Cambridge ESOL (2011, p. 3) which goes on to state that the course does not "set out a repertoire of prescribed procedures or techniques for language teaching (ibid, p. 5)." Rather, it strives to "establish a framework within which candidates can develop awareness, understanding and skills appropriate to working with a wide range of learners in a variety of contexts" (ibid).

The structure of the course is outlined in Appendix One, taken from the Cambridge ESOL DELTA modules handbook. Module One has a primarily linguistic focus, being essentially concerned with theoretical perspectives on language acquisition, understanding of terminology, theoretical approaches to the use of resources, and defining, then dealing with problems encountered by language learners. Module Two then shifts to 
more practical aspects of these areas, particularly the planning, teaching, and evaluation of lessons, and according to Borg (2011, p.371) has one of its aims as being to "develop candidates' beliefs about teaching." The third and final module develops awareness of a particular specialism and looks at aspects of course design.

Overall the DELTA incorporates aspects of both theory and practice and places an emphasis on tracking development over time, alongside an awareness of learner needs in linguistic and broader pedagogic terms. Reflection also plays a critical part over the duration of the course, with candidates expected to not only reflect before, during, and after teaching practice. This then makes the DELTA highly amenable to being studied through the theoretical lens of a teacher cognition framework, as has been done in the work of Simon Borg's (2011) qualitative longitudinal study of "the impact of in-service teacher education on language teachers' beliefs" (p.370).

The link between teacher education and teacher beliefs is further supported by Mann (2005, p. 108) who stresses the need for "a process of inner dialogue and 'conversation with self' (Prawat, 1991)" and movement towards a "cognitive space" in which "the language teacher develops awareness of practice." Again, teacher belief is an intramuscular process. Opinions, feelings, perceptions, views, and epistemologies are built up over time. Some would argue that they are constantly but most would agree that our cognitions define who we are.

This is a recurring theme within the teacher cognition literature and this paper, though not seeking to add to that area of literature, draws on epistemologies from that field of investigation. This consequently feeds into the argument at the heart of this paper which is that through teachers developing a better professional awareness and by extension a better professional practice, there are clear benefits for students. Such desirable outcomes are particularly salient in the UK context where tuition fees have increased rapidly in the past few decades, and where the borders between the education of home students and the education of international students are rapidly crumbling in the face of a shared experience.

\section{Focus of the Research Study}

Other studies which have used the DELTA as a background context for their research include Borg's (2011) aforementioned examination of its influence on language teachers' beliefs, and Kelly's (2005) synthesis of reflections on the DELTA.

In Borg's study, a total of six candidates took part. Methods used for data collection combined pre-course questionnaires with six audio-recorded semi-structured interviews. The first series of interviews were carried out face to face whilst the next four were conducted via telephone; allowing for the data to be analysed on two levels, namely "cyclical and summative" (2011, p. 372). A list of themes was then drawn up and a cross-case comparison provided in grid format. Interestingly the findings were that "the DELTA did not have a significant impact" in terms of radically altering beliefs but had more of an impact on "developmental processes" (2011, p. 378) suggestive of slow change over a period of time.

That slow change over a period of time fits in with the intramuscular analogy used at the heart of this chapter. I am interested in looking at teacher development over a period of time through a qualitative lens, shaping a narrative from the experiences of teachers in one 'smaller' context, and then seeing how this can contribute to the broader picture of enhancing student engagement and the student experience. After all, Brown \& Rodgers (2002, p.32) point out that the main goal of research is "to report your findings to the world and hopefully to help reshape that world in some small measure as a result of your study." The world I am seeking to reshape is 
teaching's relationship to marketing, and developing a greater awareness of why institutions must invest in professional development.

The factor that sets this research apart from Borg's (2011) study and much other research in the field is that this is 'insider' research as defined in Platt (1981), Robson (2002), and Rooney (2005). This is a form of research where "the researcher has a direct involvement or connection with the research setting" (ibid, 2005, p. 1). In this case, I am in charge of English Language Programmes in the organisation in which the two DELTA candidates were based when this study was undertaken. Though I was not their direct line manager I had been responsible for their recruitment and had also helped secure funding for their studies. As such I had an involvement with the interviewees on both a personal and professional level.

Arksey and Knight (1999, p.67) discuss the advantages of conducting "insider" research. Some advantages include the ease of access that is available to inside researchers; "the informed knowledge" of the study setting; the sometimes natural rapport and understanding between interviewer and interviewees; the "richer data" that can be gained through familiarity; and the fact that "the insider's familiarity enables them to discern the authenticity of the account" (ibid). There are also drawbacks to insider research, particularly in terms of generalisation and a priori knowledge, but these are counteracted by keeping "focus on learning the meaning that the participants hold about the problem or issue, not the meaning that the researchers bring to the research or writers express in the literature" (Creswell, 2009, p. 175).

\section{The Research Setting}

In this study the specific context is the provision of Foundation courses within United Kingdom higher education. These Foundation courses are essentially composed of lessons in English for Academic Purposes and introductory modules in other subjects. Gillett and Wray (2006, p.
7) describe such courses as those that "prepare lower level students for entry to higher education" over an extended or specific period of time. The term higher education is used here, rather than pre-higher education, because the provider of the courses is INTO University Partnerships, a British limited company responsible for running joint ventures with higher education institutions in the UK and the USA.

The actual location of these courses was London, where the participants live and work amongst a diverse group of teachers with a range of nationalities and specialities. Most teachers at this level would be expected to hold a Masters degree or some formal teaching qualification and one of the cornerstones of INTO's recruitment policy is that all teachers should have at least Masters or DELTA equivalence. This is also a British Council recommendation for all teachers of English for Academic Purposes.

\section{The Research Participants}

The first of the interview candidates was a young woman named Caroline who had been teaching for our organisation for about nine months before embarking on the DELTA. Caroline is a graduate of Theology from the University of Cambridge and brings to teaching that powerful and passionate sense of conscience which is often attributed to religious minded people. After graduating from Cambridge Caroline moved into English Language Teaching. She completed a CELTA course and then spent a year teaching in China before returning to the United Kingdom where she had found it difficult to get permanent work before I recruited her for this position.

The second candidate is named Eleanor, from the north of England; relatively young and inexperienced with the bulk of her teaching having come on a CELTA course and in summer schools overseas. As a consequence of just starting out on her career she had no prior experience of teaching the type of more demanding EAP courses that 
are delivered at the higher end of the English Language teaching spectrum. Essentially, at the outset of the DELTA course, Eleanor met Roberts (1998) definition of a "novice" teacher as being someone who has not "had the chance to develop any confidence in classroom management nor personal theories about language teaching" (p. 206).

Both Caroline and Eleanor, in the DELTA course, shared the same mentor who was also a teacher within the INTO organisation and who played a vital role in their development. Much has been written in the teacher education literature on the role of mentoring, not just from the perspective of teachers, both novice and experienced, being mentored, but also in light of the benefits and experience for mentors. Such works include David (2000); Monsour (2003); and Huling (2006). In the case of this study, the mentor was a teacher named Kenneth, a male in his early fifties. He is a vastly experienced teacher trainer who previously worked in Turkey and is a strong advocate of professional development for all teachers, not just novices. Kenneth's role as a mentor was not simply to provide general advice and information, but also to observe lessons, provide feedback on these, and to provide feedback on assignments.

\section{Methods Employed in the Research}

The research was carried out over a period of one year; featuring audio-recorded, semi-structured interviews with Eleanor and Caroline, and less formal discussions with their mentor, Kenneth through the duration of the DELTA course. The two main interviews, used in this study, took place one year apart, firstly at a mid-point in the course, and subsequently at a point several months after the course had finished.

The reason I opted for a semi-structured approach, as defined by Borg (2006, p. 190) is that it is flexible on account of being "directed by a set of general themes, rather than specific questions." It also allows the interaction to proceed conversationally (Kvale, 1996) "rather than as a formalized exchange" (Borg, 2006, p. 203). Furthermore Borg (ibid) states that this "enables the researcher to develop a relationship with the participants" and facilitates what Miller \& Glassner (1997, p. 106) have referred to as a fundamental "intersubjective depth." Through developing a relationship with participants, "the direction of the conversation is not predetermined" (Borg, 2006, p. 203) and "encourages interviewees to play an active part ..... rather than being passive objects to be studied (Holstein \& Gubrium, 1997)" (ibid). My desire was to capture the voices and personalities of Caroline and Eleanor as naturally as possible.

Therefore the all-round affordances of a semistructured approach allowed me to facilitate loose conversations around the framework of a basic interview guide. This guide, according to Arksey and Knight (1999, p. 97), should be based around "the key questions that the study is addressing." Furthermore, I drew on ideas such as those from Lam's (2000) study of L2 teachers' usage of technology, in which the researcher conducted semi-structured interviews with ESL teachers to explore their beliefs about technology by using a flexible interview process. He states that "the questions were by no means limited to the list, which allowed me to follow the flow of conversation and to ask for elaboration of certain points or probe other issues that were not mentioned by the participant. As a result, questions were not asked in the same order for each participant, nor were exactly the same questions asked" (2000, p. 398).

\section{Capturing the Voices of Teachers}

In order to accurately capture the dialogue that occurs in qualitative interviewing, Arksey and Knight (1999, p. 105) advocate the use of audiotaping as this has long been a feature of collecting interview data within the qualitative research paradigm. Advantages of this include the fact that there is "a permanent record" capturing "the whole of the conversation verbatim"; it facilitates critical listening both during and after the record- 
ing; and it shows serious intent on the part of the interviewer (ibid). However it can also be a timeconsuming process and can induce nervousness amongst participants. Added to this, there is the reality that "committing verbal exchanges to paper seems to result in their immediate deterioration: context, empathy, and other emotional dynamics are often lost or diminished" (Poland, 1995, p. 299), cited in Arksey and Knight (1999, p. 162). There was also the fact that I made explicit that though this was insider research, my role was as a researcher, not a manager.

To reduce the impact of nervousness, I tried to make the atmosphere as relaxed and natural as possible; a process greatly assisted by my 'insider' knowledge of participants and setting. I had to create an atmosphere that allowed Caroline and Eleanor, the young teachers, to talk about their own experience in their own terms (Arksey \& Knight, 1999, pp. 99-100). I believe I managed to do this, with Eleanor in particular, because the conversations we shared were quite lengthy and the flow of dialogue as natural as possible. Furthermore today's developments in technology have considerably reduced many of the age-old problems of audio taping interviews, and I benefitted from using a sophisticated Digital Voice Recorder.

\section{The Initial Interviews}

The key issue that I wanted to address in this research was getting a sense of English Language teachers' understanding of and beliefs about the role professional development plays in enhancing the student experience within an institution. That then could feed into broader understandings of the impact this is likely to have on developing and marketing programmes for students in international higher education.

One of the features of good qualitative interviewing is that the responses come naturally and therefore the teachers were not asked direct questions about the student experience. They were asked questions that allowed scope for a range of issues to be discussed and upon the teachers themselves speaking about the student experience, allowing scope for further spontaneous investigation of this.

Such a situation arose in the interview with Eleanor when asked how she felt that she'd developed on a personal level. After firstly talking about greater awareness of targets, aims, and outcomes, she then began to speak explicitly about students; allowing me, as interviewer, to probe this further, as outlined below.

Eleanor: So I can go in there with my aims and try and meet them but I'm also more aware that during that time other aims and other issues might arise, that it's perfectly okay to work with what comes from the students and to keep their ideas and their eccentricities in mind when you plan a class, andleave the plan of the class for that matter.

Paul (spontaneous question): So you're more conscious of the students?

Eleanor: Yeah, of what they can bring to a class. And what they need from me and also accepting that things don't go to plan, and that when they don't go to plan that doesn't necessarily mean the lesson's a failure. It just means it could succeed in other ways.

Eleanor therein has captured a sense of partnership in the learning experience but it's also important to bear in mind that researchers must be attentive not only to what is being said but also to how things are "being said, for instance emphases, and the emotional tone of the speaker" (Arksey \& Knight, 1999, p. 100). Underpinning this snapshot of dialogue, there's a sense of moving away from a didactic notion of what's right and wrong in a classroom to a more fluid, but equally controlled approach. A feeling of students being empowered and simultaneously the teacher being empowered permeates the closing line of Eleanor's speech; 
a point at which lessons are no longer viewed in terms of success or failure, but in terms of what the students actually get from the class. This, to me, also suggests movement away from an initial teacher training approach of taking each class in isolation, and shifting focus towards a more holistic sense of classes and courses developing over a period of time. Above all, not just lessons, but also aims, are part of this more fluid approach to teaching.

In another vignette of dialogue, coming out of the initial discussions, we find that Caroline describes a similar new and heightened awareness of students in a slightly different manner. In discussing the positive role of Kenneth, her mentor, she refers to the importance of taking into account "all the situations, all the things that you knew about the students" before and during the lesson. Here, she has alluded to a change in cognition with regard to approaches to delivery. She's not just thinking of students in terms of the present or future, but also the background context of the individual and shared histories they bring to the classroom.

Through the dialogic lens of these extracts, we can also see support for a claim by Roberts (1998, p. 207) in citing McIntyre (1993), that it is generally recognised that "reflection on existing practice seems to require a threshold level of confidence and classroom management." The DELTA helped provide this threshold of confidence, as expressed by both participants in the first stage of interviewing. Interestingly though neither Caroline nor Eleanor explicitly spoke about increased confidence in the first set of interviews. Rather they used terms such as being more effective, being more aware, being more conscientious, and in Eleanor's case specifically, about how her views on teaching had expanded. The feedback that she received from her tutor Kenneth further supported this, with much of his commentary making reference to how she had improved gradually as the course progressed.

\section{The Importance of Awareness}

During the initial interview, when asked if her attitudes to teaching had changed as a consequence of DELTA training, Eleanor responded that she wasn't sure they'd changed but they had certainly expanded. This expansion was then defined in the following manner which may have been informed by theory studied on the DELTA course in the form of Thornbury's (2000) Dogme teaching theory which essentially argues that "teaching should be done using only the resources that teachers and students bring to the classroom - i.e. themselves - and whatever happens to be in the classroom." Though not designed for English for Academic Purposes teaching, exposure to the theory clearly shapes new approaches to the definition of resources.

Eleanor: It's made me more aware of different attitudes, different perceptions of teaching. Some people look at teaching in completely different ways. And it's made me more aware that teaching is a lot broader, a lot, especially with English Language teaching, it encompasses everything. You can use anything to teach English.

There then followed a discussion on awareness of professional identity which had echoes of Wenger's (1998) argument that identity is a crucial aspect of practice, and Goodwyn's (1997, p. 127) view that teachers need to "review their own practice and to evaluate it in a way meaningful to them." Roberts' (1998, p. 26) describes this as teachers assimilating new ideas into "their framework of thinking about teaching." I asked the participants if their own perception of their professional identity had changed as a consequence of doing the DELTA.

Eleanor's response had strong echoes of Richards' (1998, p. 48) definition of a "developmental continuum" for teachers. This means that they go through a process whereby eventually "as they 
develop their own personal theories of teaching, they can teach more from an art-craft approach, creating teaching approaches according to the particular constraints and dynamics of the situations in which they work" (ibid). The factor though that sets Eleanor's response aside from much of the developmental literature is that these words are actually coming from a 'developing' teacher and are expressed in language and sentiments common to many young EFL practitioners.

Eleanor: Well I guess most English Language teachers sort offall accidentally into it as a method of being abroad and just supporting yourself. So while there's quite a large community of very enthusiastic young people who go out and they take teaching to keep themselves in money and a lot of them really do take it seriously and they try and give their best, I think the pyramid narrows as you get into a smaller community of very English Language focused teachers who see it more as a calling than a job. I mean for example em watching the seminars given by Scott Thornbury and actually you look at the audience and sometimes you see the same faces in three different YouTube seminars that he's given. You understand it's a much smaller, more dedicated community at this level and that they, what a lot of people will see as 'oh you just turn up with a newspaper and chat for a few hours' can actually become something a lot more in depth and detailed. I guess you can see where people get forty, fifty years worth of a career out of it rather than two or three summers.

Caroline too speaks of a heightened awareness, also linked into identity, but identity within the context of the classroom rather than the broader spectrum of the profession. When asked about the role of observations in the learning process, either those conducted by her mentor Kenneth, or peer observations either of or by herself, she spoke of how useful these were in terms of learning and seeing "a range of people teaching in different contexts"; thus being exposed to new techniques, interaction, and approaches. She then went on to speak about other areas of awareness.

Caroline: It helps you realise things you weren't aware of in your own teaching. You can be surprisingly unaware of some aspects of the way you're teaching and to have someone else come in the classroom and say you need to hold that piece of paper higher up so everyone can see it, well you know simple things and also suggest techniques that you've never tried but could actually work really well.

This new awareness came about as a consequence of doing the DELTA, and also made her a "lot more aware of how I need to sort of continually learn and how learning how to teach is not just something you kind of do once and then can do for the rest of your life." This is something that again is echoed in much of the literature on teacher education, and shows Caroline's developing awareness of the distinction that Wallace (1991, p. 3), in Crandall (2000, p. 36), summarises as being that "training or education is something that can be presented or managed by others; whereas development is something that can be done only by and for oneself."

For such self-development to occur, Wallace (1991, p. 12) argues that a trainee teacher needs to have acquired both "received" and "experiential" knowledge before they are at a level where they can reflect on that knowledge and experience in the light of their classroom practice. This experiential knowledge has also been described as a combination of "knowing in action" (Schön, 1983, pp. 49-50), and reflection defined as "turning thought back on action" (ibid, p. 10). The way in which the process of 'thought into action' is measured on the DELTA is through observation, and a sample of observational data is provided in Appendix Two. 
This data shows the role that reflection and selfevaluation has played in Caroline's development over the duration of the course and particularly in Module Two.

Evidence of awareness though is not limited to data generated through the interviews. In his feedback on lesson delivery and design, Kenneth also spoke about Eleanor's "deeper awareness" of use of language and learners' needs, which has provided more opportunities for student learning, and how she demonstrated "awareness of links between theory and practice by commenting, albeit briefly, on the potential for language development through dictation, and commented on classroom management implications in lesson evaluation." He also spoke about greater awareness on Caroline's part in areas such as grading language use and overall class management.

\section{The Role of Theory in Teacher Education}

Following on from the trainee teachers' growing awareness in a number of other areas, the interviews also revealed a growing awareness of and an interest in theory. This fits in well with the assertion of Widdowson (1997, p. 121) who suggests that teacher education is problem-oriented, with the implication of "a broader intellectual awareness of theoretical principles underlying particular practices." In my opinion, and in some of the teacher training literature, there is a sense that initial teacher training courses show teachers how to do things but not why they are doing them.

In the course of the interviews, during both stages, the participants made consistent reference to the role of theory in helping to inform their practice and develop as teachers. During her second interview Eleanor stated that "I've seen more of the academic side of English teaching, the Linguistics and the sort of theory and background, and I've taken more time to read up on journals and the journals that get sent to the library." It was not without difficulty though that Eleanor came to grasp the importance of theory, and how to apply this properly to her teaching practice. This was apparent in the comments of her tutor Kenneth in assessing her work in terms of expressing her understanding in written form. He suggested that at the outset Eleanor "experienced difficulty in expressing her ideas clearly, establishing coherent links between theory and classroom practice" However, as the course evolved, she too evolved in terms of her critical analysis and self-evaluation. This is supported by the observed changes in her teaching and deeper reading of the surrounding literature.

Caroline too, in the first interview, spoke at length about the benefits that theory brought to her teaching. She stated that "one of the things it taught me is how much there is to know about EFL and how much I still need to develop as a teacher. And all the different theories about how to teach or things like that. It really, especially Module One, there was a lot of reading and a lot of work; it sort of opened my eyes to all the literature there is out there and all the really useful authors there are that have brilliant ideas about how to teach." Again, going back to her awareness of the need for continuous professional development Caroline, describing her mentor Kenneth shows awareness of the importance of understanding the theory. She said, "I think what's impressive is that he's been in EFL teaching for many, many years and he's still keeping up with the literature. He's reading all the latest ideas."

\section{Analysing the Second Interviews}

One of the key questions in the second interviews was whether or not the DELTA trainees felt that students would notice a post-course difference in their teaching. Though this type of questioning may have lent itself to some subjectivity, I found a degree of criticality in the answers; with criticality itself being an added benefit of the course. Eleanor responded that she would hope so because everyone likes to think they are improving, but 
Caroline was not so sure that the students would notice because they may not be overtly conscious of this. The extract below shows the actual question and how she responded to it.

Paul: Do you think that if you had students from two years ago back with you now, would they notice the difference?

Caroline: I'm not sure. Students like, I think students recognise, notice things in a different way than teachers would. I think a teacher would recognise the differences but maybe a student; students are more likely to pick up on the rapport and the generalfeeling in the class and what they're doing and things. Maybe they wouldn'tpick up on the smaller issues of you know the fine details of what you're teaching and how you're teaching it and how much you know about what you're doing. But I suppose if, if they'd been taught by me a lot before and then they had a decent length of time with me now, maybe they would notice the difference.

Despite Caroline feeling that students might not notice the difference in a teacher before and after DELTA training, both participants agreed that teacher education has clear benefits for teachers themselves, for students, and for the institution as a whole. The institutional benefits are summarised by Caroline as being "because I' $m$ a better teacher so I'm doing a better job and that means that's better for INTO I think." Eleanor also suggested that through the DELTA "we can bring in or revitalise older or new ideas and pass them on to colleagues" which contributes "to the workplace as a whole." Looking at the latter response from another angle, it is also suggestive of Eleanor's increasing sense of belonging to a teaching team. She demonstrates a growing awareness of this being a subset within a wider English Language teaching community, echoing Etienne Wenger's (1998) work on Communities of Practice.
Support for this claim comes through the language that Eleanor uses in the course of the two interviews, moving away from the sense of isolation experienced by novice teachers, to a feeling of being part of a collegial environment. In many ways this collegial atmosphere was forced on Eleanor by the demands of the DELTA, perhaps Caroline too though it is more noticeable in the language of the former. In order to survive the rigours of the course she needed to interact more with her colleagues, and seeing their greater experience as an opportunity rather than as a threat. If one is to apply this to the overall context of the institution, similar relationships could be built up over time with the marketing department. Interaction can be of as much benefit to places as it can be to people, in my opinion.

\section{Getting Back to Student Perceptions}

Moving back to the research puzzle at the heart of this chapter, I asked the candidates if they felt that doing the DELTA had benefitted students. Through doing this, I was using the teachers' perceptions of how they were viewed through the eyes of students.

Here, as in many other instances throughout the interviews, a common thread emerged of both participants suggesting that the course was of benefit in terms of improving the overall shape and design of lessons and courses. This is important because that has potential benefits for marketing; of teachers being able to see the bigger picture outside the context of their own classrooms and make a respected contribution to shaping the ethos of that broader context. There was also a sense of increased knowledge coming through in the responses, detailed below in an extract of dialogue from the second and final interview.

Paul: Do you think it benefits students having teachers who have done the DELTA? 
Eleanor: Yes, I think it does. Obviously when it comes to things like organisation of lessons and looking at the reasonfororganisation often though teachers before the DELTA we were doing these things, having a warm up, then having a presentation and controlled practice, or doing a different method, maybe a group exercise, now we're more aware of why we're doing it, which means we can focus it better. Also it gives the teachers a better idea of for example organising a syllabus and instead of just bringing together a lot of ideas, it provides a framework which we can then fit those ideas a round to a more coherent, to a more finely directed series of lessons.

Paul: And is it better for students?

Caroline: Yes, yeah because I'm a lot more aware of the grammar points and sort of (pause) the CELTA gives you a general idea and then teaching gives you a lot of practical ways of dealing with groups and all that kind of thing but the DELTA gave me a lot more detail about my subject which I really needed because my degree wasn't in English. So you know really properly studying the grammar and the language systems properly was something I hadn't done very much before the DELTA. So I think I'd thought quite a lot about the skills that we teach and I felt quite good at that but teaching the systems, the discourse and the phonology and the grammar and things was something I was quite weak on before. So that's definitely helped my students.

\section{RECOMMENDATIONS}

\section{Development and Marketing}

Through the interviews and mentor feedback, there's an emergent sense of how professional development benefits teachers in a range of different ways. There is a clear sense of teachers' voices needing to be heard in their own language, and both teachers in this research articulated their feelings very honestly and conscientiously. These are young teachers, whose voices bring refreshment to the profession, and whose experience at the cutting edge of student engagement contains a great deal of information that organisations need to understand and use more productively.

Amongst these discussions, reference was made to the potential benefits for students of having teachers who are better qualified in their craft. Even if students do not consciously notice this, the teachers themselves are aware that they are providing a much better and holistic languagelearning experience for the students. Going back to the issue at the heart of this chapter, the question is then how institutions might harness this in respect of developing programmes and marketing those programmes.

Firstly in terms of developing programmes, one only needs to look at the aims of DELTA Module Three; shown in detail in Appendix Three. Basically this module is designed to develop candidates' competency in a particular specialism and to have them build a course programme around this specialism. In the words of Caroline, in the second interview, this helped her "to look at the whole term over a whole ten week block and work out what I'm going to do and where I want my students to be at the end of it." Eleanor echoed this in her second interview by saying that "it gives the teachers a better idea of for example organising a syllabus and instead of just bringing together a lot of ideas, it provides a framework which we can then fit those ideas around to a more coherent, to a more finely directed series of lessons."

The reason that this links into the student experience, and is of critical importance to institutions, is that coherence and relevance of curriculum are seen as two of the key factors in student engagement; which is at the heart of that overall experience. This was a recurring theme in the research conducted by Bryson et al (2009) in their "in depth 
investigation of students' engagement throughout their first year in university." Since the DELTA also incorporates strong elements of lesson design, candidates receive a strong foundation in preparing courses at both macro and micro levels.

Beetham and Sharpe have created the phrase "design for learning" to describe the process by which teachers "arrive at a plan or structure or design for a learning situation" (2007, p. 7). Of course they add the the proviso that "learning can never be wholly designed, only designed for" because of the contingent nature of teaching as it takes place. In the field of EAP, that contingency is central to the lives of teachers because it focuses so heavily on "specific communicative needs and practices of particular groups" (Hyland \& HampLyons, 2002, p. 2) rather than taking a generic or one size-fits-all approach to delivery.

Since the DELTA strongly advocates needsanalysis based approaches, it gives teachers a strong awareness of the contingent nature of teaching, as indeed do other courses of equivalent level in the field. It may also serve to make teachers more aware of what types of courses are necessary for students and attractive to students. This could mean that there should be more consultation with teachers when designing and marketing courses. Teachers, by virtue of spending so long at the interface with students, often know much more than marketing teams what contemporary students are actually looking for. It seems illogical that these voices are not listened to and that in some cases are actively ignored.

On the whole though I would suggest that what professional development ultimately does is not to make teachers more conscious of the micro and macro aspects of designing and delivering courses. Rather, whether consciously or not, it gives them a greater sense of having a teaching epistemology; which essentially means the beliefs they hold about teaching and how these relate to the broader ways in which they view the world. In some ways this could be seen to fit into a teacher cognition framework but on another level, it's looking at things not simply from the perspective of teachers but from the organisation as a whole. Sometimes it is necessary to take a step away from the internal perspective and view or imagine things through external eyes such as those of prospective students, who are less likely to see a dichotomy between departments.

\section{Epistemology}

Occasionally in educational organisations, especially those engaged in private enterprise, there can be disconnect in the ethos of academic and marketing departments. This can often be caused by a lack of understanding about the role teaching actually plays in 'marketing' the institution to students. Often a great deal of an institution's budget is devoted to marketing, with little regard given to the fact that there is a crossover between teaching and marketing. The fact that teachers develop a better sense of epistemology means that a particular ethos can be created in the workplace, which spreads from the academic sector to other parts of the institution.

This position is strongly supported by a UKCISA (United Kingdom Council for International Student Affairs) paper on Teaching \& Learning for International Students. They assert that "Quality teaching and learning is the linchpin of universities' internationalisation work but its importance is often overlooked" and "a sector wide approach is needed for the provision of high quality teaching and learning for international students to enhance standards, maintain sector sustainability and for capacity building of institutions and individuals" (2008, p.1). They go on to stress the importance of a powerful teaching and learning strategy because "returning international students act as ambassadors for their institution and country of sojourn and 'word of mouth' reports, as well as 'brand' identification, play major roles in maintaining the flow of international students to the UK" (ibid, p. 3). 
Similar findings have also been reached in the Australian context in the work of Chen (2006) in "an exploratory study of Asian international students searching for Australian higher education services." Therein the focus was largely about the types and characteristics of Word of Mouth advertising and communication, and their significance in terms of this informal channel of marketing for Australian universities.

Basically students have their own forms of evaluation and communication that are not limited to brochures, exhibitions, and the agendas of advertising or marketing agents. International students are in fact an awful lot smarter than that, which is something the field of English Language teaching and its practitioners have been aware of for some time; largely because ELT has its roots in a much more commercial, private sector environment than other areas of higher education have experienced in the past.

The essence of this is that if students do not have a good classroom experience they are not going to be impressed enough with an institution to recommend it to their friends and prospective fellow students; meaning that it will require a considerable amount of work on the part of any marketing department to compensate for this. Indeed no amount of marketing may fully compensate for the damage because a perception might emerge that the organisation cares more for marketing than education, which is not what any student, international or domestic, wants to hear.

This situation can possibly be avoided if marketing departments strike a better balance between corporate and academic forces driving their promotion and recruitment. Marketing departments, when budgeting, need to see the clear link between a quality teaching experience and the promotion of the institution. Therefore, rather than seeing a dichotomy in terms of budget, organisations should realise that funding for professional development is as much a part of international student marketing as the overseas trips and exhibitions that are such a major part of current marketing efforts. If this happens, every part of the institution will be better off as a result.

So often, in the literature, we come across physical analogies such as the one at the heart of this chapter. Education is often referred to as a body. If that is truly the case then ultimately the different body parts need to constantly work together in harmony.

\section{FUTURE RESEARCH DIRECTIONS}

The contemporary emphasis on the student experience within UK higher education has been quantified, on a national level, through the comprehensive National Student Survey (www. thestudentsurvey.com/) but this is tailored to the broad higher educational spectrum and not the individual needs of organisations. It would thus be interesting to shape a narrative from 'smaller', more localised contexts, and then see how this can contribute to the broader picture of student engagement. By adding small-scale qualitative inquiry to the existing quantitative data, research could deepen understanding of the phenomenon under investigation and provide representation of a "plurality of interests, voices, and perspectives" (Greene \& Caracelli, 1997, p.14).

In this particular study, described herein, Ihave concentrated on the voices of teachers starting out on their careers in the field of international education. In doing so, I have chosen to focus on the angle of the student experience but the interview data lends itself to deeper investigation from a number of angles. This suggests that there is further scope in analysing the voices of teachers, in a qualitative manner, to learn more about their beliefs and understanding of the profession and its burning issues. Borg (2006) has framed such an analysis in the theoretical lens of teacher cognition and this is a field greatly deserving of further exploration. Such an exploration is not 
possible in the context of a short chapter like this but there is a growing body of literature suggesting that teacher cognition is a rapidly emergent field of study.

\section{CONCLUSION}

In conclusion, this chapter has illustrated the importance of professional development for teachers and argued that this brings benefits to the entire institution. One of the benefits is that it gives teachers a greater sense of their role as a whole, not just in the context of individual classes and classrooms, but in terms of the broader curriculum and the educational organisation. This also has benefits for the marketing of organisations in that students are going to have a better classroom experience and this message is going to feed back to the wider market. It is for very good reason that teaching performance is at the heart of analysis within the National Student Survey, and why so much attention is being paid to this.

However, as outlined herein and clearly established by the title of the chapter, one-shot training does not fully develop either teachers or organisations as effectively as continuous professional development sessions. Though the DELTA may be an example of a training course that is delivered in a specific timeframe, as most tend to be, the ethos of the course is one of continuous reflection and ongoing development.

Reading the interviews of Caroline and Eleanor, there is a clear sense that this ethos became part of their epistemology and has benefitted them immensely in many ways. They have developed a stronger professional identity, or what could be termed as a stronger professional voice. Their teaching voices and identities have been traced over the course of a year, in the interviews I conducted, and serve as a useful lesson not just to teacher educators but all those interested in teacher cognition.
On the whole, as a researcher, the process has been rewarding and enjoyable. These young teachers, who realise they are by no means the finished model in terms of professional development, have brought great benefit to the organisation we work for. They bring freshness to the teaching team, as suggested in one of the earlier sections, and what they lack in experience they compensate for with enthusiasm and creativity. Within that too there is an element of imagination, as harnessed in DELTA module three where teachers are asked to design courses in their own specialist areas. In an increasingly competitive market, organisations are going to have to become more imaginative not just in terms of the courses they offer but also in terms of the way that they address the student experience.

Added to this, these young teachers serve as a bridge between the organisation and the student because the DELTA has made them acutely aware of student needs. They bring this intense consciousness to their teaching and that too has benefits for the organisation. Very often, from the academic perspective, marketing departments are blinded by budgets, spreadsheets, and sales figures. The alternative view is that teachers are idealistic and rarely see things beyond the context of their own classrooms; almost a pure view unpolluted by the realities of a customer-focused, targetdriven environment. Perhaps too strongly held a view on either side will inhibit the organisation unnecessarily but there has to be a middle ground where the voices of students are listened to and supported by those closest to them. The people closest to those students are very often the teachers and it is apparent in the interviews with Eleanor and Caroline that they have a considerable desire to help their students.

It will be interesting to see how these young teachers develop further in years to come, how they incorporate an intramuscular approach into their own professional development, and whether or not in this time of change, higher educational 
institutions see the benefits of such an approach. For the sake of international education and the future of English Language Teaching, and teaching as a whole, one can only hope that they do.

\section{ACKNOWLEDGMENT}

Special acknowledgement of assistance to Rob Ledbury, INTO UEA.

\section{REFERENCES}

Arksey, H., \& Knight, P. (1999). Interviewing for social scientists. London: Sage.

Astin, A. W. (1984). Student involvement: A developmental theory for higher education. Journal of College Student Personnel, 25, 297-308.

Bailey, K. M., Curtis, A., \& Nunan, D. (2001). Pursuing professional development. Boston: Heinle \& Heinle.

Beetham, H., \& Sharpe, R. (2007). Rethinking pedagogy for a digital age: Designing and delivering e-learning. New York: Routledge.

Borg, S. (2006). Teacher cognition and language education: Research and practice. London: Continuum.

Borg, S. (2011). The impact of in-service teacher education on language teachers' beliefs. System, 39(3), 370-380. doi:10.1016/j.system.2011.07.009.

Brown, J. D., \& Rodgers, T. (2002). Doing applied linguistics research. Oxford, UK: Oxford University Press.

Bryson, C., \& Hand, L. (2007). The role of engagementininspiring teaching and learning. Innovations in Teaching and Education International, 44(4), 349-362. doi:10.1080/14703290701602748.
Bryson, C., Hardy, C., \& Hand, L. (2009). An in-depth investigation of students' engagement throughout their first year in university. London: University College London.

Chen, C. H. (2006). Word-of-mouth information gathering: An exploratory study of Asian international students searching for Australian higher education services. Retrieved from eprints.qut. edu.au/16275/1/Chia-Hung_Chen_Thesis.pdf

Chickering, A. W., \& Gamson, Z. F. (1987). Seven principles for good practice in undergraduate education. AAHE Bulletin, 3(7).

Cook, A., \& Leckey, J. (1999). Do expectations meet reality? A survey of changes in first-year student opinion. Journal of Further and Higher Education, 23(2), 157-171. doi:10.1080/0309877990230201.

Crandall, J. (2000). Language teacher education. Annual Review of Applied Linguistics, 20, 34-55. doi:10.1017/S0267190500200032.

Creswell, J. (2009). Research design - Qualitative, quantitative, and mixed methods approaches. London: SAGE.

Crookes, G., \& Chandler, P. M. (2001). Introducing action research into the education of postsecondary foreign language teachers. Foreign Language Annals, 34(2), 131-140. doi:10.1111/j.1944-9720.2001.tb02818.x.

David, T. (2000). Programs in practice: Teacher mentoring - Benefits all around. Kappa Delta Pi Record, 36(3), 134-136. doi:10.1080/00228958 .2000.10532039.

Edge, J. (2003). Teacher development. Birmingham, UK: Aston University.

Evans, L. (2002). What is teacher development? Oxford Review of Education, 28(1), 123-137. doi:10.1080/03054980120113670. 
Fredericks, J. A., Blumenfeld, P. C., \& Paris, A. H. (2004). School engagement: Potential of the concept, state of the evidence. Review of Educational Research, 74, 59-109. doi:10.3102/00346543074001059.

Gibbons, M., \& Norman, P. (1987). An integrated model for sustained staff development. In Wideen, M., \& Andrews, I. (Eds.), Staff Development For School Improvement-A Focus on the Teacher (pp. 103-110). Philadelphia, PA: The Falmer Press.

Gillett, A. J., \& Wray, L. (2006). EAP and success. In Gillett, A. J., \& Wray, L. (Eds.), Assessing the effectiveness of EAP programmes (pp. 1-11). London: BALEAP.

Golombek, P. R., \& Johnson, K. E. (2004). Narrative inquiry as a mediational space: Examining cognitive and emotional dissonance in second language teachers' development. Teachers and teaching. Theory into Practice, 10, 307-327.

Goodwyn, A. (1997). Developing English teachers: The role of mentorship in a reflective profession. Milton Keynes, UK: Open University Press.

Greene, J. C., \& Caracelli, V. J. (1997). Defining and describing the paradigm issues in mixedmethod evaluation. In Greene, J. C., \& Caracelli, V. J. (Eds.), Advances in mixed-method evaluation: The challenges and benefits of integrating diverse paradigms (pp. 5-18). San Francisco, CA: Jossey-Bass. doi:10.1002/ev.1068.

Holstein, J. A., \& Gubrium, J. F. (1997). Active Interviewing. In Silverman (Ed.), Qualitative Research: Theory, method and practice. London: Sage.

Huling, L. (2006). Overview and framework. In Dangel, J. R. (Ed.), Teacher education yearbook XIV: Research on teacher induction (pp. 1-3). Lanham, MD: Rowman \& Littlefield Education.
Hyland, K., \& Hamp-Lyons, L. (2002). EAP: Issues and directions. Journal of English for Academic Purposes, 1(1), 1-12. doi:10.1016/ S1475-1585(02)00002-4.

Kelly, G. (2005). Can the DELTA help you to teach EAP? Retrieved from www.developingteachers.com

Kuh, G. (2006). National survey of student engagement: Conceptual framework and psychometric properties. Retrieved from http://nsse.iub.edu/ nsse_2001/pdf/framework-2001.pdf

Kuh, G. D. (2001). Assessing what really matters to student learning: Inside the national survey of student engagement. Change, 33(3), 10-17, 66. doi:10.1080/00091380109601795.

Kvale, S. (1996). Interviews: An introduction to qualitative research interviewing. London: SAGE.

Lam, Y. (2000). Technophilia vs. technophobia: A preliminary look at why second-language teachers do or do not use technology in their classrooms. Canadian Modern Language Review, 56(3), 390-420. doi:10.3138/cmlr.56.3.389.

Lowe, H., \& Cook, A. (2003). Mind the gap: Are students prepared for higher education. Journal of Further and Higher Education, 27(1), 53-76. doi:10.1080/03098770305629.

Mann, S. (2005). The language teacher's development. Language Teaching, 38(3), 103-108. doi:10.1017/S0261444805002867.

McIntyre, D. (1993). Theory, theorizing and reflection in initial teacher education. In Calderhead, J., \& Gates, P. (Eds.), Conceptualising Reflection in Teacher Development (pp. 39-52). London: Falmer.

Miller, J., \& Glassner, B. (1997). The 'inside' and the 'outside': Finding realities in interviews. In Silverman, D. (Ed.), Qualitative Research: Theory, Method and Practice. London: Sage. 
Monsour, F. (2003). Mentoring to develop and retain new teachers. Kappa Delta Pi Record, 39, 134-135. doi:10.1080/00228958.2003.10516393.

Motteram, G. (2004). Blended education and the transformation of teachers: A long-term case study in postgraduate UK highereducation. Paper presented at Network Learning Conference (2004). London, UK.

Pennington, M.C.(1990). A professional development focus for the language teaching practicum. In Richards, J. C., \& Nunan, D. (Eds.), Second Language Teacher Education (pp. 132-151). Cambridge, UK: CUP.

Platt, J. (1981). On interviewing one's peers. The British Journal of Sociology, 32(1), 75-91. doi:10.2307/589764.

Poland, B. (1995). Transcription quality as an aspect of rigor in qualitative research. Qualitative Inquiry, 1(3), 290-310. doi:10.1177/ 107780049500100302.

Prawat, R. (1991). Conversations with self and settings: A framework for thinking about teacher empowerment. American Educational Research Journal, 28(4), 737-757. doi:10.3102/00028312028004737.

Ramsden, P. (2009). The future of higher education teaching and the student experience. Retrieved from www.bis.gov.uk/he-debate-ramsden

Richards, J., \& Lockhart, C. (1994). Reflective teaching in the second language classroom. Cambridge, UK: CUP. doi:10.1017/ CBO9780511667169.

Richards, J. C. (2008). Second language teacher education today. RELC Journal, 39(2), 158-177. doi:10.1177/0033688208092182.

Roberts, J. (1998). Language teacher education. London: Arnold.
Robson, C. (2002). Real world research. Oxford, UK: Blackwell Publishing.

Rooney, P. (2005). Researching from the inside - Does it compromise validity? Dublin Institute of Technology, 3 .

Schlager, M. S., \& Fusco, J. (2003). Teacher professional development, technology, and communities of practice: Are we putting the cart before the horse? The Information Society, 19(203).

Schon, D. A. (1983). The reflective practitioner: How professionals think in action. London: Temple Smith.

Shulman, L. S. (1988). Disciplines of inquiry in education: An overview. In Jaeger, R. M. (Ed.), Complementary methods for research in education (pp. 3-17). Washington, DC: AERA.

Sokol, M. (2011). Delta is equal to a masters, says regulator. EL Gazette. Retrieved from http:// mag.digitalpc.co.uk

Stuart, C., \& Thurlow, D. (2000). Making it their own: Preservice teachers' experiences, beliefs, and classroom practices. Journal of Teacher Education, 51(2), 113-121. doi:10.1177/002248710005100205.

Thornbury, S. (2000). A dogma for EFL. IATEFL Issues, 153(2).

Tomlinson, B. (2003). Developing materials to develop yourself. Humanising Language Teaching. 5(3).

Trowler, V. (2010). Student engagement literature review. The Higher Education Academy. Retrieved from http://www.heacademy.ac.uk/ assets/documents/studentengagement/StudentEngagementLiteratureReview.pdf 
UK CISA Publications. (2008). PMI project on international student teaching and learning issues. UKCISA TALIS Initiative. Retrieved from www. ukcisa.org.uk/files/.../talis_position_paper_december_2008.doc

Wallace, M. (1991). Training foreign language teachers: A reflective approach. Cambridge, UK: CUP.

Weber, S. (2004). The success of open source. Cambridge, MA: Harvard University Press.

Wenger, E. (1998). Communities of practice: Learning, meaning, and identity. New York: Cambridge University Press.

Widdowson, H. (1997). Approaches to second language teacher education. In Tucker, G. D., \& Corson, D. (Eds.), Encyclopaedia of language and education: Second language education (pp. 121-129). London: Kluwer Academic Publishers. doi:10.1007/978-94-011-4419-3_12.

\section{ADDITIONAL READING}

Borg, S. (2009). Language teacher cognition. In Burns, A., \& Richards, J. C. (Eds.), The Cambridge Guide to Second Language Teacher Education. Cambridge, UK: Cambridge University Press.

Borg, S., \& Alshumaimeri, Y. (2012). University teacher educators' research engagement: Perspectives from Saudi Arabia. Teaching and Teacher Education, 28(3), 347-356. doi:10.1016/j. tate.2011.10.011.

Bryson, C., \& Hand, L. (2007). Do staff conceptions of good teaching and learning approaches align with enhancing student engagement? Paper presented at Higher Education Research and Development Society of Australia Conference. Adelaide, Australia.
Bryson, C., Hardy, C., \& Hand, L. (2009). An in-depth investigation of students' engagement throughout their first year in university. Paper presented at UK National Transition Conference: Research and Good Practice in Promoting Student Engagement in the First Year. London, UK.

Buchanan, D., \& Jackson, S. (1998). Supporting self-evaluation in initial teacher education. Scottish Educational Review, (30): 110-124.

Edwards, B. (1999). Inside the whale: Deep insider research. Retrieved from http://www.aare. edu.au/99pap/edw99006.htm

Lahteenoja, S., \& Pirttila-Backman, A. M. (2005). Cultivation or coddling? University teachers' views on student integration. Studies in Higher Education, 6(30), 641-661. doi:10.1080/03075070500339970.

Mann, S. (2001). Alternative perspectives on the student experience: Alienation and engagement. Studies in Higher Education, 26(1), 7-19. doi:10.1080/03075070020030689.

Smyth, A., \& Holian, R. (1999). The credibility of the researcher who does research in their own organisation: The perils of participant observation. Paper presented at the Association of Qualitative Research Conference: Issue of Rigour in Qualitative Research. Melbourne, Australia.

VanHeugten, K. (2004). Managinginsiderresearch: Learning fromexperience.Qualitative Social Work, 3(2), 203-219. doi:10.1177/1473325004043386.

Walker, J. (2011). English language teaching management research in post-compulsory contexts: Still 'crawling out'? Research in Post-Compulsory Education, 16(4), 489-508. doi:10.1080/135967 48.2011.630919.

Workman, B. (2007). Casing the joint: Explorations by the insider-researcher preparing for work -based projects. Retrieved from eprints.mdx. ac.uk/5211/2/Workman-Casing_the_joint2.pdf 
Wyatt, M., \& Borg, S. (2011). Development in the practical knowledge of language teachers: A comparative study of three teachers designing and using communicative tasks on an in-service BA TESOL programme in the Middle East. Innovation in Language Learning and Teaching, 5(3), 233-252. doi:10.1080/17501229.2010.537340.

Zhao, C. M., \& Kuh, G. (2004). Adding value: Learning communities and student engagement. Research in Higher Education, 2(45), 115-138. doi:10.1023/B:RIHE.0000015692.88534.de.

\section{KEY TERMS AND DEFINITIONS}

DELTA: Internationally recognised English Language teaching diploma equivalent to a Masters degree and \& regulated by Cambridge ESOL.

English for Academic Purposes: Preparation for students in the linguistic and practical approaches required to begin or complete academic studies in the context of second language education; usually at a further or higher level.

Insider Research: Research conducted within an organisation that the researcher works for, or is closely involved with.
Intramuscular: A form of medical treatment, normally by injection, which is administered over a period of time rather than in a single one-shot solution.

Marketing in English Language Teaching: The promotion of courses and organisations which provide studies in various fields of English Language teaching.

Student Experience: Umbrella term for the feelings and perception of students with regard to their educational experience, generally within higher education.

Teacher Cognition: A theoretical construct which has emerged in recent decades to describe the complexity of teachers' 'mental lives' (Borg, 2006).

Teacher Development/Teacher Education: Terms often used interchangeably to describe the process of continuous professional development undertaken by teachers.

Teacher Training: Term generally used to describe the courses and qualifications that teachers undertake and receive at the outset of their careers, or one-off courses that are largely designed with a short-term or immediate purpose in mind. 


\section{APPENDIX 1}

Table 1. Overview of the DELTA

\begin{tabular}{|l|l|l|}
\hline \multicolumn{1}{|c|}{ Module } & \multicolumn{1}{|c|}{ Title } & \multicolumn{1}{c|}{ Assessment Format } \\
\hline ONE & $\begin{array}{l}\text { Understanding Language, Methodology and } \\
\text { Resources. }\end{array}$ & $\begin{array}{l}\text { A written examination } \\
\text { consisting of two parts, } \\
\text { for Teaching each 1 hour 30 minutes (externally } \\
\text { marked). }\end{array}$ \\
\hline TWO & Developing Professional Practice. & $\begin{array}{l}\text { Assessed assignments incorporating background } \\
\text { essays and observed teaching. }\end{array}$ \\
\hline THREE & $\begin{array}{l}\text { Extending Practice and ELT specialism (e.g. } \\
\text { Teaching } \\
\text { young learners, } \\
\text { Special Purposes, Teaching } \\
\text { one-to-one). }\end{array}$ & $\begin{array}{l}\text { An extended assignment of 4,000 to 4,500 } \\
\text { words (externally marked). }\end{array}$ \\
\hline
\end{tabular}

\section{APPENDIX 2}

\section{Table 2. Observational data for Caroline}

\begin{tabular}{|c|c|}
\hline Skills Area & Observer Feedback \\
\hline Planning and preparation of lessons. & $\begin{array}{l}\text { From early on in the course, Caroline planned and prepared her lessons with a degree of } \\
\text { independence, and identified appropriate aims and outcomes for her learners. She is now } \\
\text { able to prepare lessons that have clear and limited aims, and sequence activities and tasks } \\
\text { logically to lead to their achievement. She needs to continue to think about selection of } \\
\text { materials and task that provide challenge to an often diverse group of learners. }\end{array}$ \\
\hline $\begin{array}{l}\text { Awareness of and response to learners and } \\
\text { learning. }\end{array}$ & $\begin{array}{l}\text { Caroline has a positive classroom manner and is sensitive to the needs (linguistic, cultural } \\
\text { and affective) of individual learners, and the class as a whole. She is supportive and } \\
\text { interested in her learners. Caroline monitors effectively and responds to learners' } \\
\text { contributions to lessons with praise and encouragement. She is developing an awareness } \\
\text { of errors (PDA stage } 3 \text { ) and needs to continue to explore this area. }\end{array}$ \\
\hline $\begin{array}{l}\text { Teaching skills, procedures, techniques, and } \\
\text { classroom management. }\end{array}$ & $\begin{array}{l}\text { Caroline has made significant improvements in several areas, both in those areas focussed } \\
\text { on in the PDA (teacher language use, wait time and getting more from the resources and } \\
\text { materials available) and those arising from her own reflections (classroom interaction, } \\
\text { PDA stage 4). Caroline organises her classes to suit tasks and aims, monitors effectively } \\
\text { and has learned to set up and manage activities more efficiently. For this latter point she } \\
\text { needs to plan carefully when setting up and managing more complex tasks. Caroline } \\
\text { has also learned to integrate technology into her lessons. While Caroline is beginning to } \\
\text { correct more, she needs to continue to think about students' errors and develop a range of } \\
\text { techniques for dealing with these (LSA2 \& 3). }\end{array}$ \\
\hline Reflection and evaluation of lessons. & $\begin{array}{l}\text { Throughout PDA stages 1-4, Caroline has made insightful comments on her teaching } \\
\text { practices and beliefs. She is able to set developmental targets and evaluate the } \\
\text { effectiveness of techniques, procedures and methods used to monitor progress using } \\
\text { a range of evaluation tools. Caroline also monitors learning carefully and uses data } \\
\text { to adjust teaching in the lesson and across a series of lessons. There was evidence of } \\
\text { good reflection in teaching practice, particularly with reference to the students, though } \\
\text { reflection on planning was lacking on occasion (LSA2). Oral feedback for LSA2 \& } 3 \\
\text { took place before written self-evaluation was submitted because of timetabling / school } \\
\text { holiday issues. }\end{array}$ \\
\hline
\end{tabular}




\section{APPENDIX 3}

Figure 1. Outline of DELTA Module Three, reproduced from DELTA Modules Handbook-Cambridge ESOL Publications

\section{MODULE ШाWR}

EXTENDING PRACTICEAND ELTSPECIALISM

\section{Introduction to Delta Module Three}

Wodule There ains to devlop cendidates' howldoge of and competense in:

- a chosen specialism

- approoches to needs analysis

- curriculum and spillabus design principles

- different types of syllabus

- course design and exaluation

- assessment of learners.

To actieve these aims, candidates need to:

- Desearch a chosen specialism

- undesstand and use appeopriate methods of needs analysia diagnostic assessment for a spectic grop of learners

- undenstand and apply key principles underpinning 5yllbbus design and course planring

- consider learder assessment and course wimation

- synthesise all thei learninginto a project which can be coherently presented to a third party.

The fal syllaba an be downloaded at

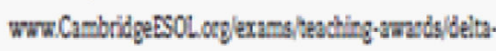
modularhtml

The mod the is assessed by means of a 4,000-4,500 wod Extended Assignment in which candidates cary out an independent investigaticn leating to the design of a course programme velated to their chosen specialst ares.
- Teacting in a noo-Englist-speaking enrironment, (NDSE)

- Teacting learners online/through distance blended leaning (DU)

- Teacting Inglish to learners with special requirements eq visua/hearing impairment, fyleria, ASD (SR)

- Language devibipment for teachers (DT)

- Languge support (e.g on mainstream teaching programmes, specialist skills suppot, such as supporting witing naeds) (1S)

Candidates may choose to nanow down the selected specialsem in order to research a specific aspect in appropriate depth, e. ' 'EF' may be nanowed down to Teaching communicution shils to dotors worting in a ganeal hospitat; Teacting young leaners can be narwod dowa to Designing curse prournes for 11-12 year old karners in Hong Reng: Teaching moncingual learners can be lirked to a specitic

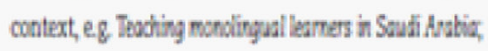
Teacting FCE may be the focus of the specialism $\alpha$ may be narowed down to hequing laners for FCE littring stils tests. Howere, candidates shodd not narnow the fros to a discrete sub-sbill such as reating for gist or a discrete area of gammar such as teaching future tenses. 